\title{
Exploring functions of the lost seeking devices for people with dementia
}

\author{
Yung-Ching Chen ${ }^{\mathrm{a}^{*}}$, Cherng-Yee Leung ${ }^{\mathrm{b}}$ \\ ${ }^{a}$ The Graduate Institute of Design Science, Tatung University, Taipei, Taiwan (R.O.C.) \\ ${ }^{\mathrm{b}}$ The Department of Industrial Design, Tatung University, Taipei, Taiwan (R.O.C.)
}

\begin{abstract}
This paper utilized a user-centered design approach as the foundation for technology in dementia care in order to improve the quality of telemedicine service. A status-quo analysis and questionnaire survey were conducted to explore the actual needs of the elders in using the lost seeking devices and the problems they encountered. In total, 37 caregivers for people with dementia were surveyed ( 20 female, 17 male, $\mathrm{M}=50.08, \mathrm{SD}=15.47)$. The dementia-patients: 16 are male, 21 female $(\mathrm{M}=72.75, \mathrm{SD}=10.23)$. Through analysis and induction, 3 problems were identified: poor information transmission, low user acceptance, individual material security anxiety. 2-4 improvement proposals are suggested for each problem. Most care-givers hope technological products would increase the efficiency and safety, but they also think it's too expensive and lack of computer skills. This result demonstrates the choice of seeking methods depends on the education level of the caregivers and most of them are elders. The concern of data leakage is also related to today's fraud issue, which may be the reason limiting the promotion of electronic products and biometrics. Further research is required, suggesting researchers should pursue improvements in lost seeking design devices in dementia for caregivers.
\end{abstract}

Keywords: care-givers, Dementia, e-Health, Safety, Telemedicine services, User-Centered Design, Wandering

\section{Introduction}

As elderly population expands, there has been an interest in the relationship between Gerontology and e-Health. In the e-era, e-Health is an important issue. While all seem to agree that e-Health cannot be entirely separate from market forces, opinions differ as to how e-Health programs should relate to the real word of users. Nowadays, some institutes apply this kind of service through lost seeking devices to help find lost people, especially for dementia-patients. However, the users' behaviors and opinions related with these devices are still unknown. Recent usercentered design (UCD) research has suggested that Telemedicine service may indeed facilitate processes beneficial to users using. This study focuses on the functions of lost seeking devices for people with dementia. Based on the user-centered design (UCD) concept, this paper is therefore the intent of present study to examine users' needs and requirements. And followed by a comparison with the findings of ex- pected the results could be used as the foundation for technology in dementia-patient care.

Dementia is now recognized as a global issue of increasing importance, affecting some 24 million people around the world [3]. After age 65, the likelihood of developing dementia roughly doubles every five years. At the age of 85 , the odds of a person developing it are close to 50 percent. In Taiwan, the population of demented elders has been up to a million. Dementia is a disruptive chronic illness with complex syndromes, and that can be caused by a number of progressive disorders that affect memory, thinking, behavior and the ability to perform everyday activities [5]. The dementia patients suffered from disabilities and their family members undertook extremely great burden. The neuropsychiatric changes in dementia are nearly universal and may result in extremely challenging management problems [6], and heavy burden on caregivers.

However, wandering behavior is the reason that many family members unable to take care the de-

\footnotetext{
*Corresponding authors. Emails: d9804001@ms.ttu.edu.tw, leung@ttu.edu.tw
} 
mented elders in the house [8][9]. The most controversial application of technology for dementia care in e-Health and telemedicine services is seen in the application of tracking and surveillance equipment. Proponents of these technologies argue that the technologies reduce caregiver stress and increase individual autonomy since they allow the person with dementia having freedom to move around as they wish [7][18]. Critics however argue that these technologies are an infringement of people's civil liberties and undermine the personhood of the individual [16]. However, assistive technology is a key aspect of improving healthcare. Bjørneby et al. [14] stated that the technologies should: (1) give a feeling of independence to the person; (2) support the person in making choices; (3) have a positive impact on his/her life; (4) support skills maintained or do not emphasize lost skills; (5) not focus on the user as a person with disabilities, but supports the self image of being a person with abilities; (6) remind the solutions that existed before; (7) the use of the products is possible by the information visible/available at all times. They [13][14] further elaborated on this and presented an adaptation of design for all principles in development of assistive technology for people with dementia.

The existing technologies and systems are often expensive and unsuitable. Choosing the appropriate assistive technology is not always easy and there is a wide range of different technologies that can be adapted and used for people with dementia to cope with the practical problems encountered in daily life [15]. The UCD model advocates a design process that involves users in the whole design process in order to match the product to the user requirements and to increase its practical use [18][10]. This study adopted the UCD approach to investigate the processes, devices, and methods employed in dementia care, especially for lost seeking.

This paper is divided into six main sections. Section 1 provides some background information about the beginning of the project. Section 2 outlines the overview solutions for getting lost or wandering. Section 3 describes the interview with questionnaire. Section 4 summarizes results and analysis. Section 5 delineates some of the problems encountered. Finally, the implications of findings are discussed.

\section{Overview solutions for getting lost or wandering}

The main character of dementia is the decline of their memory and learning comprehension [4]. Due to the problem of memory and orientation, wandering behaviors and easily-to-be-lost always happens on dementia-sufferers [17]. There are $37 \%$ of dementiapatients developing to have wandering behaviors [2]. When they are lost, it is very important to help them and prevent them from wandering. Today, to the family members of the missing elders, they can only report to the (1) Seeking Center of Missing Elders: Report to the Seeking Center of Missing Elders, connecting to the police network; (2) Police network: Report to the local police office when family is missing, providing them detailed and complete information, such as their clothing, hair style, blood type, age, gender, height, and obvious characters; (3) Poster: Post posters in public places through the seeking center; (4) Broadcast media: Ask for audience's help through the Police Radio Station; (5) Cable station: Announce the seeking information through local cable stations; (6) Hospital: Inquire the emergency center of local hospitals, or provide them photos to identify. The consequences of getting lost or wandering are very diverse. Wandering and disorientation may cause them with anxiety, boring, or less exercise [1][11][12].

Outdoor activity is important to the dementiapatients. Since the patients are level and situationdependent, the demand from caregivers and individual care-giving environment are different from one by one. Some lost seeking devices with e-Health system are developed and marketed.

There are roughly three kind of lost seeking devices: non-electronic, electronic, and biometric (Table 1). Most of them are small, easy to wear and carry around, not easily loose, and water-proofing, strong features, but the sizes and usage are different. Each product has its own pros and cons, and can be featured: (1) By the usage: portable, wearable, and biometric; (2) By the materials: paper, plastics, and stainless steel, et al; (3) By the labeled information: photo, name, emergency contact number, address, sufferer's history of chronic cases, battery and system operating signals, and function bottoms. 
Table 1

Overview of solutions for the lost seeking devices in dementia

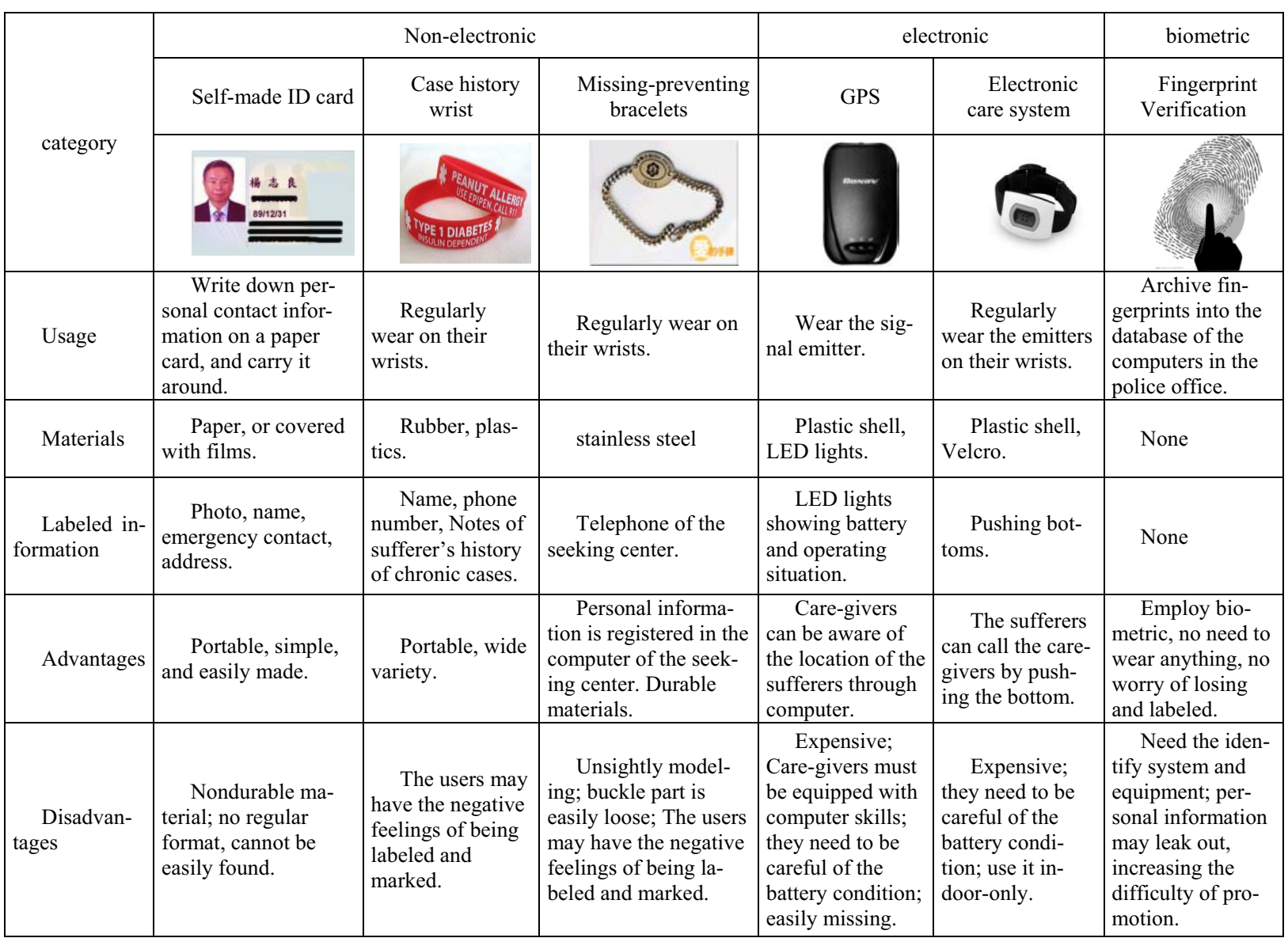

\section{Research methods}

\subsection{Interview with Questionnaire}

The study was designed to answer the following research question: Do caregivers and family members of dementia-patients using the lost seeking- devices perform significantly better? This study investigated this question by constructing and administering a depth interview, questionnaire survey, to proceed caregivers and family members of dementiapatients opinion investigate. The contents of the questionnaire include subject's personal information, disorientation experience, and their experiences and advices of using the lost seeking- devices. The purpose of the questionnaires is to understand the experience and requirements towards currently available products for dementia-patients. Researchers visited the subjects with the company of social workers. In- formed consent was obtained from each participant after a full explanation of the questionnaire and its procedures was provided. Each face to face interview spent about 40 minutes. Each received a gift for participation. The collected data are analyzed by descriptive statistics. Analysis was conducted using the SPSS-PC (Version 12.0) statistical software package.

\subsection{Subjects}

This study cooperated with the Seeking Center of Missing Elders. Social workers were asked to evaluate the 37 voluntary subjects. The subjects who volunteered take part in the study were 37 caregivers and family members of dementia-patients. The sample included caregivers and family members of dementia-patients from a wide range of household areas. The qualified subjects are: (1) taking care of adult dementia-patients who are above mild level; (2) taking care of patients having Disability Certificates; or 
(3) taking care of patients who have experienced disorientation.

\section{Results and Analysis}

\subsection{Subject's Personal Information}

Table 2 presents the results of the 37 care-givers in this study. Their ages (20 female, 17 male) were from 28 to 86 years old $(\mathrm{M}=50.3, \mathrm{SD}=15.47)$. The dementia-patients: 16 are male, 21 female, and their ages were from 40 to 93 years old $(\mathrm{M}=72.68, \mathrm{SD}=$ 10.23). The education levels of the caregivers were: below junior high school (24.3\%), high school $(40.5 \%)$, college $(27 \%)$, above graduate school $(8.1 \%)$; the profession of the caregivers: homemaker $(32.4 \%)$, business $(32.4 \%)$, industry $(16.2 \%)$, freelance $(13.5 \%)$, and government employees $(5.4 \%)$.
The relationship between care-givers and patients, the most is the older generation $(70.2 \%)$, and then spouse $(18.9 \%)$. Living with dementia-patients $67 \%$ $(\mathrm{n}=25)$; not living together $12 \%(\mathrm{n}=33)$. The lost seeking devices used by the dementia-patients: the most is self-made ID card (62.1\%); the least is case history wrist, GPS and electronic care system. The lost seeking devices which dementia-patients have used: the most is Missing-preventing bracelets (43.2\%); self-made ID card (35.1\%); electronic care system $(13.5 \%)$; the least is case history wrist $(0 \%)$, and 3 care-givers $(8.1 \%)$ have no experience. The duration of using the lost seeking devices: the longest is 84 months, the shortest is 3 months $(\mathrm{M}=25.65$, $\mathrm{SD}=25.44)$. The computer competency of caregivers and family members of dementia-patients are: excellent $11 \%(\mathrm{n}=4)$; good $11 \%(\mathrm{n}=4)$; bad $78 \%(\mathrm{n}=$ 29).

Table 2

ANOVA table for the lost seeking devices in dementia

\begin{tabular}{|c|c|c|c|c|c|c|c|c|}
\hline Source & $\begin{array}{c}M \\
(\mathrm{n}=37)\end{array}$ & $\begin{array}{l}\text { Self-made } \\
\text { ID card } \\
(\mathrm{n}=13)\end{array}$ & $\begin{array}{l}\text { Missing - pre- } \\
\text { venting bracelets } \\
\quad(\mathrm{n}=16)\end{array}$ & $\begin{array}{c}\text { GPS } \\
(n=5)\end{array}$ & $\begin{array}{l}\text { No expe- } \\
\text { rience } \\
(\mathrm{n}=3)\end{array}$ & $F$ & $p$ & Post hoc \\
\hline Caregivers age & 50.3 & 53.77 & 50.88 & 41.2 & 47.33 & 0.824 & .490 & \\
\hline Patients age & 72.68 & 70.77 & 72.94 & 79.2 & 68.67 & 1.503 & .232 & \\
\hline Living with dementia-patients & & 10 & 12 & 3 & 0 & & & \\
\hline Not Living together & & 3 & 4 & 2 & 3 & & & \\
\hline The number of lost & 4.14 & 4.23 & 4.06 & 3.4 & 5.33 & 0.464 & .710 & \\
\hline Use of time (month) & 25.65 & 38.08 & 24.13 & 13.6 & $\mathrm{~N} / \mathrm{A}$ & 3.013 & 0.044 & \\
\hline The lost distance of $1^{\text {st }}(\mathrm{km})$ & 3.43 & 3.54 & 2.81 & 2.8 & 7.33 & 4.899 & .006 & $123<4$ \\
\hline The lost distance of $2^{\text {nd }}(\mathrm{km})$ & 2.62 & 1.85 & 2.31 & 3.8 & 5.67 & 6.872 & .001 & $\begin{array}{l}12<34 \\
123<4 \\
1<234 \\
\end{array}$ \\
\hline The lost distance of $3^{\text {rd }}(\mathrm{km})$ & 2.32 & 1.77 & 2.06 & 2.4 & 6 & 5.433 & .004 & $123<4$ \\
\hline
\end{tabular}

\subsection{Wandering Behavior}

Table 3 presents the results of the one-mean $t$ test. During all three phases, the mean dementia-patients Sex, Age and lost distance were showing no statistically significant; Furthermore, the Correlation Coefficient of lost distance among $1^{\text {st }}, 2^{\text {nd }}, 3^{\text {rd }}$, time lost were statistically significant $(\mathrm{p}<0.05)$ (Table 4$)$; Three groups of variables on the correlation coefficient showed a high degree of correlation between each other, and are of significant level, Three groups of variables on the results show that the $1^{\text {st }}$ and $2^{\text {nd }}(\mathrm{r}$
$=0.381, \mathrm{p}=0.020)$ were highly correlated with $1^{\text {st }}$ the $3^{\text {rd }}(\mathrm{r}=0.385, \mathrm{p}=0.019)$, and the $2^{\text {nd }}$ and $3^{\text {rd }}(\mathrm{r}=$ $0.489, \mathrm{p}=0.002)$. Table 5 presents the results of the paired t-test of lost distance among $1^{\text {st }}, 2^{\text {nd }}, 3^{\text {rd }}$. Group $1(p=0.035)$ and Group $2(p=0.006)$ was significant, but Group $3(\mathrm{p}=0.347)$ was not significant. 
Table 3

Means and standard deviations of sex, age and distance from the lost distance among $1^{\text {st }}, 2^{\text {nd }}, 3^{\text {rd }}$, time lost of the 37 dementiapatients.

\begin{tabular}{|c|c|c|c|c|c|c|}
\hline Source & \multicolumn{2}{|c|}{$M$} & \multicolumn{2}{c|}{$S D$} & $t$ & $p$ \\
\hline Sex & $\begin{array}{l}\text { Female } \\
(\mathrm{n}=21)\end{array}$ & $\begin{array}{l}\text { Male } \\
(\mathrm{n}=16)\end{array}$ & $\begin{array}{l}\text { Female } \\
(\mathrm{n}=21)\end{array}$ & $\begin{array}{l}\text { Male } \\
(\mathrm{n}=16)\end{array}$ & & \\
\hline Age & 71.90 & 73.69 & 9.486 & 7.050 & -.630 & .183 \\
\hline $\begin{array}{c}\text { Frequency } \\
\text { of lost }\end{array}$ & 4.24 & 4.00 & 2.385 & 2.066 & .318 & .506 \\
\hline $1^{\text {st }}(\mathrm{km})$ & 3.10 & 3.88 & 1.895 & 2.553 & -1.068 & .192 \\
\hline $2^{\text {nd }}(\mathrm{km})$ & 2.71 & 2.50 & 1.901 & 1.673 & .357 & .343 \\
\hline $3^{\text {rd }}(\mathrm{km})$ & 2.43 & 2.19 & 1.690 & 2.316 & .366 & .764 \\
\hline \multicolumn{7}{|c|}{ a. Computed using alpha $=0.05$} \\
\hline
\end{tabular}

Table 4

Correlation Coefficient of lost distance among $1^{\text {st }}, 2^{\text {nd }}, 3^{\text {rd }}$, time lost.

\begin{tabular}{|c|c|c|}
\hline Frequency & $2^{\text {nd }}$ & $3^{\text {rd }}$ \\
\hline $1^{\text {st }}$ & $.381(\mathrm{p}=.020)$ & $.385(\mathrm{p}=.019)$ \\
\hline $2^{\text {nd }}$ & & $.489(\mathrm{p}=.002)$ \\
\hline \multicolumn{2}{|c|}{ a. Computed using alpha $=0.05$} & \\
\hline
\end{tabular}

Table 5

Paired t-test of lost distance among $1^{\text {st }}, 2^{\text {nd }}, 3^{\text {rd }}$, time lost.

\begin{tabular}{|c|c|c|c|c|c|}
\hline Source & Frequency & $M$ & $S D$ & $t$ & $p$ \\
\hline \multirow{2}{*}{ Group 1} & $1^{\text {st }}$ & \multirow{2}{*}{.811} & \multirow{2}{*}{2.246} & \multirow{2}{*}{2.195} & \multirow{2}{*}{.035} \\
\hline & $2^{\text {nd }}$ & & & & \\
\hline \multirow{2}{*}{ Group 2} & $2^{\text {nd }}$ & \multirow{2}{*}{1.108} & \multirow{2}{*}{2.319} & \multirow{2}{*}{2.907} & \multirow{2}{*}{.006} \\
\hline & $3^{\text {rd }}$ & & & & \\
\hline \multirow{2}{*}{ Group 3} & $1^{\text {st }}$ & \multirow{2}{*}{.297} & \multirow{2}{*}{1.898} & \multirow{2}{*}{.953} & \multirow{2}{*}{.347} \\
\hline & $3^{\text {rd }}$ & & & & \\
\hline \multicolumn{6}{|c|}{ a. Computed using alpha $=0.05$} \\
\hline
\end{tabular}

\subsection{The Functions in Lost Seeking Devices}

Table 6 presents the results of the one-mean $t$ test $\left(\mu_{0}=3\right)$. Degrees of freedom is 36 , of which GPS $(p=$ 0.475), Infrared Communication $(p=0.669)$, below the level of significance. That caregivers of GPS, infrared transmission function of the functional importance of the demand is not high. Table 7 presents results of the One-Way ANOVA with blocking for Importance of the functions in lost seeking devices in dementia for Caregivers. Among the 17 functions, the Importance of the functions in lost seeking devices was significant $(\mathrm{p}<0.0001)$. Post-test analysis for multiple comparisons, the least significant difference (Least Significant Dif- ference LSD) is 0.4625 . The results can be divided into five groups, respectively (SD memory card, USB, Voice Response, compass, Lamplight, Battery), (Infrared Communication, GPS), (Shockproof design, Preference for Appearance, color, weight, Waterproof design, volume), (Preference for Appearance, color, weight, Waterproof design, Volume, Easyness in Operation, Stability), (weight, Waterproof design, Volume, Easyness in Operation, Stability, Comfort).

$$
\text { Table } 6
$$

One-mean t-test of the functions in lost seeking devices in dementia for Caregivers. $\left(\mu_{0}=3\right)$

\begin{tabular}{|c|c|c|c|c|c|}
\hline No & Source & $M$ & $S D$ & $t$ & $p$ \\
\hline 1 & Weight & 4.1 & 0.92 & 7.523 & .000 \\
\hline 2 & Volume & 4.2 & 0.92 & 8.068 & .000 \\
\hline 3 & Color & 3.9 & 1.02 & 5.311 & .000 \\
\hline 4 & $\begin{array}{l}\text { Preference for } \\
\text { Appearance }\end{array}$ & 3.9 & 1.10 & 4.932 & .000 \\
\hline 5 & $\begin{array}{l}\text { Easyness in } \\
\text { Operation }\end{array}$ & 4.3 & 0.88 & 8.991 & .000 \\
\hline 6 & Stability & 4.4 & 0.75 & 10.911 & .000 \\
\hline 7 & Comfort & 4.4 & 0.69 & 12.649 & .000 \\
\hline 8 & $\begin{array}{l}\text { Waterproof } \\
\text { design }\end{array}$ & 4.1 & 0.99 & 7.167 & .000 \\
\hline 9 & $\begin{array}{l}\text { Shockproof } \\
\text { design }\end{array}$ & 3.8 & 1.29 & 3.831 & .000 \\
\hline 10 & Compass & 2.3 & 1.29 & -3.318 & .002 \\
\hline 11 & Battery & 2.4 & 1.36 & -2.653 & .012 \\
\hline 12 & Lamplight & 2.4 & 1.23 & -3.067 & .004 \\
\hline 13 & GPS & 3.2 & 1.60 & .721 & .475 \\
\hline 14 & $\begin{array}{l}\text { Infrared } \\
\text { Communica- } \\
\text { tion }\end{array}$ & 2.9 & 1.52 & -.432 & .669 \\
\hline 15 & USB & 2.1 & 1.29 & -4.319 & .000 \\
\hline 16 & $\begin{array}{l}\text { SD memory } \\
\text { card }\end{array}$ & 2.1 & 1.36 & -4.105 & .000 \\
\hline 17 & $\begin{array}{l}\text { Voice Re- } \\
\text { sponse }\end{array}$ & 2.2 & 1.46 & -3.275 & .002 \\
\hline
\end{tabular}

Table 7

One-Way ANOVA table of Importance of the functions in lost seeking devices in dementia for Caregivers.

\begin{tabular}{|c|c|c|c|c|c|}
\hline Source & $S S$ & $d f$ & $M S$ & $F$ & $p$ \\
\hline Subjects & 269.93 & 36 & 7.498057 & 7.308557 & $8.39 \mathrm{E}-29$ \\
\hline functions & 500.0064 & 16 & 31.2504 & 30.4606 & $3.26 \mathrm{E}-66$ \\
\hline Error & 590.9348 & 576 & 1.025929 & & \\
\hline Sum & 1360.871 & 628 & & & \\
\hline
\end{tabular}




\subsection{The Information in Lost Seeking Devices}

Table 8 presents the results of the one-mean $\mathrm{t}$ test $\left(\mu_{0}=3\right)$. Degrees of freedom is 36 , of which Emergency Medication $(p=0.275)$, Personal Photo $(p=$ $0.474)$, Personal alarm $(p=0.162)$, below the level of significance. That caregivers of Emergency Medication, Personal Photo, and Personal alarm information of the importance of the demand is not high. Table 9 presents results of the One-Way ANOVA with blocking for Importance of the information in lost seeking devices in dementia for Caregivers. Among the 13 functions, the Importance of the information in lost seeking devices was significant $(\mathrm{p}<0.0001)$. Post-test analysis for multiple comparisons, the least significant difference (Least Significant Difference LSD) is 0.486034 . The results can be divided into six groups, respectively (Compass, Blood pressure, Date and Time, Temperature data), (Blood pressure, Date and Time, Temperature data, Heart rate, Personal alarm), (Personal alarm, Personal Photo), (Personal Photo, Emergency Medication, GPS), (GPS, Care Center phone number), (Care Center phone number, Address, Emergency contact phone number).

Table 8

One mean t-test for Importance of the Information in lost seeking devices in dementia for Caregivers. $\left(\mu_{0}=3\right)$

\begin{tabular}{|c|l|c|c|c|c|}
\hline No & \multicolumn{1}{|c|}{ Source } & $M$ & $S D$ & $t$ & $p$ \\
\hline 1 & $\begin{array}{l}\text { Emergency contact } \\
\text { phone number }\end{array}$ & 4.9 & 0.36 & 32.111 & .000 \\
\hline 2 & Address & 4.5 & 0.90 & 10.215 & .000 \\
\hline 3 & $\begin{array}{l}\text { Seeking Center of } \\
\text { Missing Elders } \\
\text { phone number }\end{array}$ & 4.6 & 0.68 & 14.481 & .000 \\
\hline 4 & $\begin{array}{l}\text { Care Center phone } \\
\text { number }\end{array}$ & 4 & 1.27 & 4.792 & .000 \\
\hline 5 & $\begin{array}{l}\text { Emergency Medi- } \\
\text { cation }\end{array}$ & 3.3 & 1.48 & 1.108 & .275 \\
\hline 6 & GPS & 3.63 & 1.28 & 2.961 & .005 \\
\hline 7 & Personal Photo & 3.2 & 1.36 & .723 & .474 \\
\hline 8 & Personal alarm & 2.7 & 1.27 & -1.428 & .162 \\
\hline 9 & Compass & 2.1 & 1.18 & -4.888 & .000 \\
\hline 10 & Date and Time & 2.3 & 1.17 & -3.793 & .001 \\
\hline 11 & Blood pressure & 2.3 & 1.12 & -4.035 & .000 \\
\hline 12 & Heart rate & 2.5 & 1.26 & -2.217 & .033 \\
\hline 13 & Temperature data & 2.5 & 1.22 & -2.705 & .010 \\
\hline
\end{tabular}

One-Way ANOVA table of Importance of the Information in lost seeking devices in dementia for Caregivers.

\begin{tabular}{|c|c|c|c|c|c|}
\hline Source & $S S$ & $d f$ & $M S$ & $F$ & $p$ \\
\hline Subjects & 137.6091 & 36 & 3.822476 & 3.37888 & $1.29 \mathrm{E}-09$ \\
\hline Information & 434.6694 & 12 & 36.22245 & 32.01885 & $2.05 \mathrm{E}-52$ \\
\hline Error & 488.7152 & 432 & 1.131285 & & \\
\hline Sum & 1060.994 & 480 & & & \\
\hline
\end{tabular}

\subsection{The Fault in Lost Seeking Devices}

Table 10 presents the results of the one-mean $t$ test $\left(\mu_{0}=3\right)$. Degrees of freedom is 36 , of which Too Heavy $(p=0.359)$, Unstable $(p=0.058)$, Fitness $(p=$ $0.281)$, Complex Operation ( $\mathrm{p}=0.683)$, Difficult to identify $(p=0.417)$, Leakage of personal information $(p=0.218)$, below the level of significance. Table 11 presents results of the One-Way ANOVA with blocking for Importance of the fault in lost seeking devices in dementia for caregivers. Among the 13 functions, that Importance of the fault in lost seeking devices was significant $(\mathrm{p}<0.0001)$. Post-test analysis for multiple comparisons, the least significant difference (Least Significant Difference LSD) is 0.476333 . The results can be divided into four groups, respectively (Short Battery Time, Short of Light), (Complex Operation, Too Heavy, Difficult to identify, Fitness, Leakage of personal information, Unstable, Easy to fall off, Poor color, Uncomfortable, Inconvenient to Take off), (Unstable, Easy to fall off, Poor color, Uncomfortable, Inconvenient to Take off, Being Labeled).

Table 10

One mean t-test for Importance of the fault in lost seeking devices in dementia for Caregivers. $\left(\mu_{0}=3\right)$

\begin{tabular}{|c|l|c|c|c|c|}
\hline No & \multicolumn{1}{|c|}{ Source } & $M$ & $S D$ & $t$ & $p$ \\
\hline 1 & Too Heavy & 3.2 & 1.42 & .928 & .359 \\
\hline 2 & Unstable & 3.4 & 1.34 & 1.956 & .058 \\
\hline 3 & $\begin{array}{l}\text { Inconvenient to } \\
\text { Take Off }\end{array}$ & 3.7 & 1.25 & 3.292 & .002 \\
\hline 4 & Uncomfortable & 3.6 & 1.32 & 2.996 & .005 \\
\hline 5 & Poor color & 3.6 & 1.32 & 2.865 & .007 \\
\hline 6 & Easy to fall off & 3.5 & 1.33 & 2.357 & .024 \\
\hline 7 & Fitness & 3.3 & 1.50 & 1.094 & .281 \\
\hline 8 & Complex Operation & 3.1 & 1.59 & .412 & .683 \\
\hline 9 & Difficult to identify & 3.2 & 1.60 & .822 & .417 \\
\hline 10 & Short Battery Time & 2.4 & 1.50 & -2.412 & .021 \\
\hline 11 & Short of Light & 2.5 & 1.41 & -2.338 & .025 \\
\hline 12 & $\begin{array}{l}\text { Leakage of person- } \\
\text { al information }\end{array}$ & 3.4 & 1.70 & 1.255 & .218 \\
\hline 13 & Being Labeled & 3.8 & 1.54 & 3.316 & .002 \\
\hline
\end{tabular}


Table 11

One-Way ANOVA table of Importance of the fault in lost seeking devices in dementia for Caregivers.

\begin{tabular}{|c|c|c|c|c|c|}
\hline Source & $S S$ & $d f$ & $M S$ & $F$ & $p$ \\
\hline Subjects & 519.1393 & 36 & 14.42054 & 13.27153 & $7.01 \mathrm{E}-50$ \\
\hline fault & 84.29106 & 12 & 7.024255 & 6.464572 & $1.26 \mathrm{E}-10$ \\
\hline Error & 469.4012 & 432 & 1.086577 & & \\
\hline Sum & 1072.832 & 480 & & & \\
\hline
\end{tabular}

\subsection{Purchase Consideration}

Table 12 presents the results of the one-mean t test $\left(\mu_{0}=3\right)$. Degrees of freedom is 36 , The test was significant $(\mathrm{p}=0.000)$. Table 13 presents results of the One-Way ANOVA with blocking for the Purchase consideration in lost seeking devices in dementia for Caregivers. Among the 8 functions, the Importance of the Purchase consideration in lost seeking devices were not significant $(\mathrm{p}=0.074)$. Post-test analysis for multiple comparisons, the least significant difference (Least Significant Difference LSD) is 0.304181 . The results can be divided into two groups, respectively (Price, Weight, Material, Color, Appearance, Wear Type), (Color, Appearance, Wear Type, Acceptance for dementia-patients).

Table 12

One mean t-test for Importance of the Purchase consideration in lost seeking devices in dementia for Caregivers. $\left(\mu_{0}=3\right)$

\begin{tabular}{|c|l|c|c|c|c|}
\hline No & \multicolumn{1}{|c|}{ Source } & $M$ & $S D$ & $t$ & $p$ \\
\hline 1 & Weight & 4.0 & 1.04 & 6.004 & .000 \\
\hline 2 & Material & 4.1 & 1.03 & 6.692 & .000 \\
\hline 3 & Color & 4.2 & 0.93 & 7.615 & .000 \\
\hline 4 & Appearance & 4.2 & 1.01 & 6.970 & .000 \\
\hline 5 & Wear Type & 4.3 & 1.02 & 7.591 & .000 \\
\hline 6 & $\begin{array}{l}\text { Easyness in Op- } \\
\text { eration }\end{array}$ & 4.2 & 0.95 & 7.814 & .000 \\
\hline 7 & Price & 4.0 & 1.28 & 4.624 & .000 \\
\hline 8 & $\begin{array}{l}\text { Acceptance for } \\
\text { dementia-patients }\end{array}$ & 4.5 & 0.80 & 11.061 & .000 \\
\hline
\end{tabular}

Table 13

One-Way ANOVA table of Importance of the Purchase consideration in lost seeking devices in dementia for Caregivers.

\begin{tabular}{|c|c|c|c|c|c|}
\hline Source & $S S$ & $d f$ & $M S$ & $F$ & $p$ \\
\hline Subjects & 185.8649 & 36 & 5.162913 & 11.69842 & $2.94 \mathrm{E}-36$ \\
\hline $\begin{array}{c}\text { Purchase } \\
\text { consideration }\end{array}$ & 5.783784 & 7 & 0.826255 & 1.872175 & 0.074541 \\
\hline Error & 111.2162 & 252 & 0.441334 & & \\
\hline Sum & 302.8649 & 295 & & & \\
\hline
\end{tabular}

\subsection{Some advices obtained from subjects in the interview}

Some advices obtained from subjects in the interviews can be summarized in Table 14 .

Table 14

Some advices obtained from subjects in the interview

\begin{tabular}{|c|c|c|}
\hline No & Question & Results and statistics \\
\hline 1 & $\begin{array}{l}\text { Do you think who should use this } \\
\text { device? }\end{array}$ & \\
\hline $1-\mathrm{a}$ & More than 65 years of age & Agree: $6(16 \%)$ \\
\hline $1-b$ & Have a Disability Certificate & Agree: $16(43 \%)$ \\
\hline $1-\mathrm{c}$ & $\begin{array}{l}\text { Mild dementia who need assis- } \\
\text { tance }\end{array}$ & Agree: $17(46 \%)$ \\
\hline $1-d$ & Elder who has lost one or more & Agree: $33(89 \%)$ \\
\hline $1-\mathrm{e}$ & $\begin{array}{l}\text { Elder with diagnosed Mild demen- } \\
\text { tia and lost record }\end{array}$ & Agree: $27(73 \%)$ \\
\hline $1-f$ & Elders with Chronic illness & Agree: $10(27 \%)$ \\
\hline $1-\mathrm{g}$ & Mental Retarded & Agree: $19(51 \%)$ \\
\hline $1-\mathrm{h}$ & Mental Disorder & Agree: $20(54 \%)$ \\
\hline $1-\mathrm{i}$ & $\begin{array}{l}\text { Elder whose family member re- } \\
\text { quest for }\end{array}$ & Agree: 28 (76\%) \\
\hline 2 & $\begin{array}{l}\text { Do you agree with applying high- } \\
\text { tech to seeking-assist facility for } \\
\text { demented elders? }\end{array}$ & $\begin{array}{l}\text { Yes: } 33(89.1 \%) \\
\text { No: } 4(10.8 \%)\end{array}$ \\
\hline 3 & $\begin{array}{l}\text { Are there any concern of leakage } \\
\text { of personal information on the } \\
\text { application of high-tech to seek- } \\
\text { ing-assist facility for demented } \\
\text { elders? }\end{array}$ & $\begin{array}{l}\text { Yes: } 15(40.5 \%) \\
\text { No: } 22(59.4 \%)\end{array}$ \\
\hline
\end{tabular}

\section{Conclusion and Discussions}

The general principle of seeking method and product design is suggested as follows: (1) Identification of the products: the products should be worn at a clear position and with vivid color, which would help people quickly find the contact information and increase the efficiency. (2) Since the youngest caregiver was 40 years old, and the average age of subjects was 72 years old, their computer skills should be put in concern, if telemedicine service is implemented. (3) The acceptance of the product: reducing the resistance of dementia-patients, and designing the products not easily to dismantle. We should also consider the habits and types of male, female, and patients in different levels. (4) Development of the local reporting system in the community: Since dementiapatients usually get lost in their neighborhood, and there are also $25.3 \%$ care-givers and family members would choose seeking center, $56.7 \%$ choose police office, a network connecting the office of village 
chief, recreation center, police office, the seeking center, and an online toll free assistance centre should be set up for convenience locating the lost.

In this paper, we have presented a user-centered design approach to investigate the processes, devices, and methods employed in dementia care, especially for lost seeking. From the above discussion, we propose that the seeking products and methods should be re-examined and redesigned. More researches should be implemented in order to increase the sufferers' preference to use the products, and reduce the burden of the care-givers. The contributions for intentionbased functionality discovery, user-centric service selection for Caregivers, and intuitive service integration have been illustrated respectively. Further research is required, particularly to guide improvements in lost seeking design devices in dementia for Caregivers.

\section{6. limitations}

This study discovers the problems of current seeking method and facilities, investigating 37 caregivers' opinions, and concluding some suggestions. However, it is very difficult to have subjects willing to take the test. The subjects were mostly recruited from the Seeking Center of Missing Elders, and they mostly live in Taipei City and Taipei Country. It means they may not be the representative of the target population. Therefore, the conclusion of this study probably can only be applied to the Taipei metropolitan. Future research should explore the other towns into our research and further discuss the opinions of care-givers towards seeking methods and facilities.

\section{Acknowledgement}

Thanks for the cooperation of the Seeking Center of Missing Elders, and the financial support from the ROC National Science Counsel (NSC99-2221-E036-032), and the Tatung University (B99-D01-071).

\section{References}

[1] B. Fjeldsoe, A. Marshall, and Y. Miller, Behavior change interventions delivered by mobile telephone short-message service, American Journal of Preventive Medicine, vol. 36, no. 3, 2009, pp. 165-73.

[2] C. G. Ballard, R. N. C. Mohan, and C. Bannister, Wandering in dementia suffers, Int J Geriatr Psychiatry, vol. 6, 1991, pp. 611-614.

[3] C. P. Ferri, M. Prince, C. Brayne, H. Brodaty, L. Fratiglioni, M. Ganguli, K. Hall, K. Hasegawa, H. Hendrie, Y. Huang, A. Jorm, C. Mathers, P. R. Menezes, E. Rimmer, and M. Scazufca, Global prevalence of dementia: a Delphi consensus report, Lancet, vol. 366, 2005, pp. 2112-2117.

[4] D. L. Algase, Wandering in dementia, Annu Rev Nurs Res, vol. 17, 1999, pp. 185-217.

[5] G. Demiris, L. B. Afrin, S. Speedie, K. L. Courtney, M. Sondhi, V. Vimarlund, C. Lovis, W. Goossen, and C. Lynch, Patient-centred applications: use of information technology to promote disease management and wellness, Journal of the American Medical Informatics Association, vol. 15, no. 8, 2008, pp. 121-126.

[6] I. Leroi, and C. G. Lyketsos, Neuropsychiatric aspects of dementia. in: Dementia, A. Burns, J. O'Brien, D. Ames, and H. Arnold, eds, 2005.

[7] J. C. Hughes, and S. L. Louwe, Electronic tagging of people with dementia who wander, BMJ, vol. 325, 2002, pp. 847-884

[8] K. D. Bail, Electronic tagging of people with dementia: devices may be preferable to locked doors, BMJ, vol. 326, no. 7383 , 2003, pp. 218.

[9] M. Mapstone, T. M. Steffenella, and C. J. Duffy, A visuospatial variant of mild cognitive impairment: getting lost between aging and AD, Neurology, vol. 60, 2003, pp. 802-808.

[10]R. D. Buurman, User-centered design of smart products. Ergonomics, vol. 40, 1997, pp. 1159-1169.

[11]R. Passini, C. Rainville, N. Marchand, and Y. Joanette, Wayfinding in dementia of the Alzheimer type: planning abilities, J Clin Exp Neuropsychol, vol 17, 1995, pp. 820-832.

[12]R. Passini, C. Rainville, N. Marchand, and Y. Joanette, Wayfinding in a nursing home for advanced dementia of the Alzheimer's type, Environment and Behavior, 2000, pp. 684-707.

[13]S. Bjørneby, P. Duff, and O. Mraki, Developing assistive technology for people with dementia, Assistive Technology Shaping the Future, G Craddock, ed., IOS Press, 2003, pp. 781-786.

[14]S. Bjørneby, P. Topo, and T. Holthe, Technology, ethics and dementia, Norwegian Centre for Dementia Research, 1999.

[15] S. Brianna, B. A. Fjeldsoe, L. M. Alison, and D. M. Yvette, American Journal of Preventive Medicine, vol. 36, no. 2, 2009, pp. 165-173.

[16] S. Cahill, Technologies may be enabling, BMJ, 2003, pp. 281.

[17] S. M. C. Rasquin, C. Willems, S. de Vlieger, R. P. J. Geers, and $\mathrm{M}$. Soede, The use of technical devices to support outdoor mobility of dementia patients, Technology and Disability, vol. 19, 2007, pp. 113-120.

[18]T. Kontogiannis, and D. A. Embrey, User-centred design approach for introducing computer-based process information systems, Appl Ergonomics, vol. 28, no. 2, 1998, pp. $109-119$. 